\title{
A NEW LIQUID MEDIUM WITHOUT BLOOD AND SERUM FOR CULTURE OF HEMOFLAGELLATES
}

\author{
MOYSES SADIGURSKY AND CLAUDIA I. BRODSKYN \\ Gonçalo Moniz Research Center, FIOCRUZ, Federal University of Bahia, Salvador, Brazil
}

\begin{abstract}
A liquid medium without blood or serum was developed for cultivation of hemoflagellates. To a basic LIT medium containing liver infusion broth and tryptose, a mixture of RPMI 1640 and Medium 199 was added. This combination permitted high parasite yields useful for biochemical and immunological studies.
\end{abstract}

Many different media have been used for the cultivation of hemoflagellates. These media can be classified into three major categories: biphasic, semi-solid and liquid media. All principal biphasic and semi-solid media require blood as an important factor for replication of the parasites, ${ }^{1-3}$ and most other liquid media require fetal bovine serum (FBS) or blood as an essential factor. ${ }^{4-10}$ Disadvantages of these media include the expense of FBS and the fact that blood components complicate immunological and biochemical studies.

In the present paper we report a monophasic medium without blood or serum which is easy to prepare and which supports continuous growth after repeated subcultures yielding large numbers of parasites.

\section{MATERIALS AND METHODS}

The composition of the basic medium (LIT) was liver infusion broth (Difco) $2.5 \mathrm{~g}$, tryptose (Difco) $5 \mathrm{~g}, \mathrm{NaCl} 4 \mathrm{~g}$, glucose $2 \mathrm{~g}, \mathrm{KCl} 0.4 \mathrm{~g}$, and $\mathrm{Na}_{2} \mathrm{HPO}_{4} 3.15 \mathrm{~g}$, dissolved in 1 liter of water distilled twice. After adjusting the $\mathrm{pH}$ to 7.4, the medium was autoclaved, cooled and $25 \mathrm{mg}$ of hemin, dissolved in $1 \mathrm{ml}$ of $1 \mathrm{~N} \mathrm{NaOH}$ was added.

To this basic medium $1 \%$ of a $20 \times$ mixture of RPMI 1640 and Medium 199 (Difco) was added just before use. A 1-liter package of Medium 199 was added to a 1-liter package of RPMI 1640 and both were mixed with $100 \mathrm{ml}$ of water to yield a $20 \times$ concentrated solution. The $\mathrm{pH}$ was adjusted to 7.4 with $\mathrm{NaHCO}_{3}$. This concentrate is referred to as $\mathbf{R} 9$.

The parasites were cultured in 15-ml test tubes

Accepted 2 May 1986. containing $10 \mathrm{ml}$ of medium or in $72-\mathrm{cm}^{2}$ plastic culture flasks containing $25 \mathrm{ml}$ of medium, at $25^{\circ} \mathrm{C}$ without shaking. Flasks were incubated horizontally.

Parasite growth in the following media was compared: LIT + R9, NNN, 1.2 Warren's medium, ${ }^{4}$ LIT $+5 \%$ heat-inactivated FBS, LIT without additives and the medium of Berens et al. ${ }^{10}+5 \%$ FBS. Several combinations of LIT medium and $\mathrm{R} 9$ were tested.

\section{Parasites}

Leishmania mexicana amazonensis (MHOM/ BR/76/LTB 012 Josefa) and $L$. donovani chagasi (MHOM/BR/79 LI 01 Imperatriz) and one strain of Trypanosoma cruzi were cultivated. These Leishmania were typed by isoenzymes, monoclonal antibodies and DNA buoyant density and were provided by Philip Marsden (University of Brasilia). The strain of $T$. cruzi, isolated from a human patient, was provided by Sonia Andrade (Federal University of Bahia).

Infectivity of parasites after 80,50 and 10 subcultures for $L$. chagasi, T. cruzi and L. M. amazonensis, respectively, was tested in hamsters and in $\mathrm{BALB} / \mathrm{c}$ mice.

SDS-PAGE of different concentrations $(1 \times$, $5 \times$ and $10 \times)$ of the medium was done using the method of Laemmli. ${ }^{11}$

\section{RESULTS}

A comparison of the growth of $L$. d. chagasi in different media in 15-ml test tubes is shown in Figure 1. The growth in NNN, Warren's medium, LIT $+5 \%$ FBS, Berens et al. medium + $5 \% \mathrm{FBS}$, and LIT $+1 \% \mathrm{R} 9$ was very similar. The stationary phase occurred between days 4 


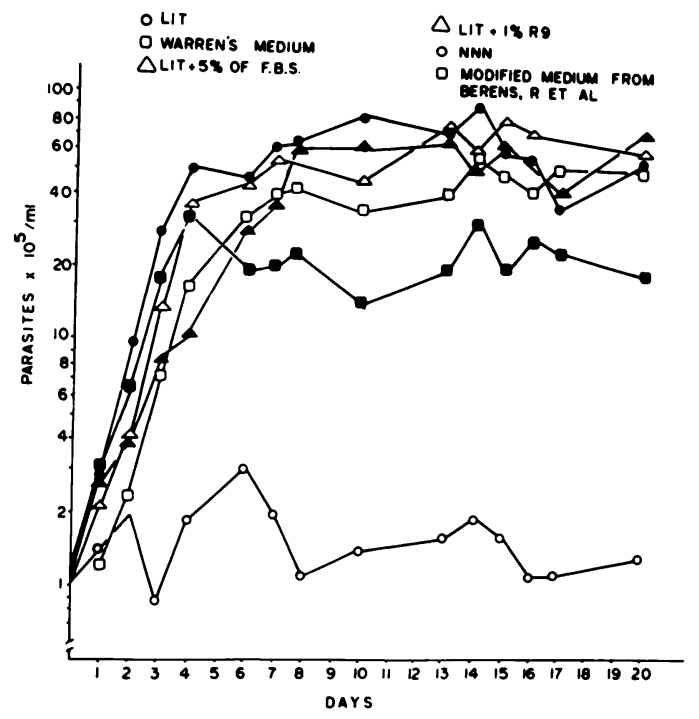

Figure 1. Growth curves of $L$. d. chagasi in different media. Cultures were incubated at $25^{\circ} \mathrm{C}$ in 15 $\mathrm{ml}$ test tubes containing $10 \mathrm{ml}$ of medium.

and 7. The basic LIT medium did not support proliferation of the parasites.

Figure 2 represents the growth of $L$.d. chagasi and $T$. cruzi in $72-\mathrm{cm}^{2}$ flasks containing $25 \mathrm{ml}$ of medium. Under these conditions a maximum of $9 \times 10^{7} L . d$. chagasi promastigotes per $\mathrm{ml}$ was observed and the stationary phase occurred around the 12 th day. At the 20th day approximately $80 \%$ of the $T$. cruzi were the infective form, trypomastigotes, as determined morphologically. The growth of $L$. m. amazonensis was very similar to that of $L$. $d$. chagasi.

Infectivity of the three different species of parasites was consistently observed. Hamsters infected with $5 \times 10^{7}$ promastigotes of $L . d$. chagasi at the stationary phase had severe disease after 4 months of infection.

Cutaneous lesions of $L$. m. amazonensis in $\mathrm{BALB} / \mathrm{c}$ mice infected subcutaneously with $1 \times$ $10^{7}$ promastigotes occurred after the second week. Blood forms of $T$. cruzi were seen in BALB/c mice infected with $10^{5}$ parasites after the 3rd day of infection, and the maximum number of parasites occurred at the 14 th day.

SDS-PAGE of the medium did not show any protein band.

\section{DISCUSSION}

The LIT $+1 \%$ R9 medium without use of blood or serum promoted good growth of par-

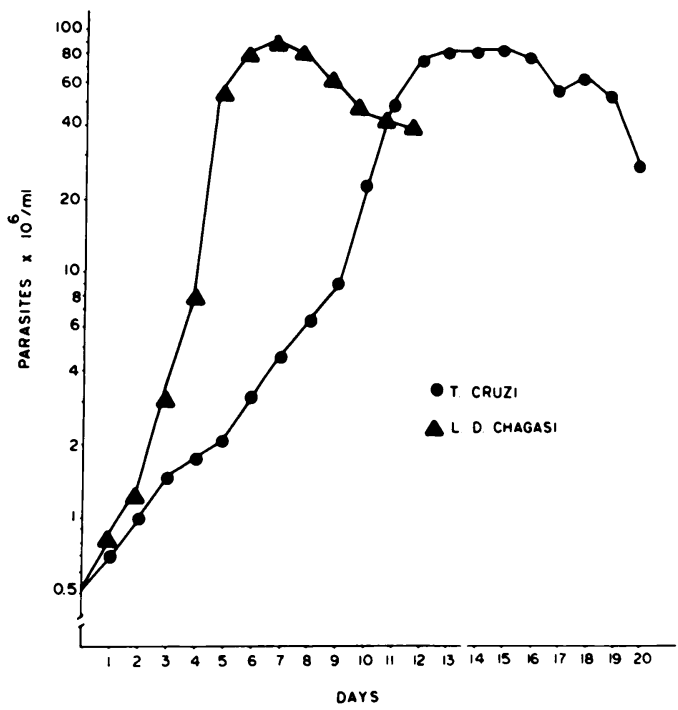

FIGURE 2. Growth curves of $L . d$. chagasi and $T$. cruzi in LIT $+1 \%$ R9. Cultures were incubated in a $72-\mathrm{cm}^{2}$ flask containing $25 \mathrm{ml}$ of medium.

asites. It is very easy to prepare and is less expensive than most other liquid media. Medium 199 and RPMI 1640, both with FBS, have been used by other authors. ${ }^{10.12}$ The absence of blood or serum did not affect infectivity of the parasites. The data show the importance of combining LIT with RPMI 1640 and Medium 199. The combination of $1 \mathrm{ml}$ of $\mathrm{R} 9$ to $100 \mathrm{ml}$ of LIT yielded the maximum number of parasites and made the medium less expensive, but the addition of more than $2 \mathrm{ml}$ of $\mathrm{R} 9$ also gave a good yield. The hyperosmolarity due to the addition of the concentrated mixtures of RPMI and Medium 199 did not seem to affect the parasites.

The defined medium of Berens and Marr ${ }^{13}$ did not give good growth to $L$. d. chagasi or $T$. cruzi and it was not possible to maintain the parasites for more than three serial passages (data not shown).

The advantage of our new medium is the possibility of obtaining parasites free of serum contaminants and suitable for biochemical and immunological studies. Labeling of parasites with radioisotopes such as ${ }^{35} \mathrm{~S}$ is easy, since it is possible to transfer parasites to RPMI medium without methionine and then add ${ }^{35} \mathrm{~S}$-methionine. Another important advantage of this medium is for the study of metabolic products of the parasites and purification of these products without contaminants. 


\section{ACKNOWLEDGMENTS}

This work was supported by grant AI 16282 from the National Institutes of Health.

\section{REFERENCES}

1. Novy, F. G., and MacNeal, W. J., 1904. On the cultivation of Trypanosoma brucei. J. Infect. Dis., 1: 1-30.

2. Nicole, C. H., 1908. Culture du parasite du Bouton d'Orient. Comptes rendu. Hebdomadaire Sci. Acad. Sci. Paris, 146: 842-843.

3. Marin, F., De Lomas, J. G., and Garcia-Penarrubia, P., 1982. Mass cultivation of Leishmania. Ann. Soc. Bel. Med. Trop., 62: 169-171.

4. Warren, L. G., 1960. Metabolism of Schizotrypanum cruzi (Chagas) I. Effect of culture and substrate concentration on respiratory rate. J. Parasitol., 45: 529-539.

5. Dwyer, D. M., 1972. A monophasic medium for cultivating Leishmania donovani in large numbers. J. Parasitol., 58: 847-848.

6. Mansour, N. S., Hady, J., and McConnell, E., 1973. A modified liquid medium for Leishmania. $J$. Parasitol., 59: 1088-1090.
7. Pan, C. T., 1971. Cultivation and morphogenesis of Trypanosoma cruzi in improved liquid media. J. Protozool., 18: 556-560.

8. Pan, A. A., 1984. Leishmania mexicana: Serial cultivation of intracellular stages in cell-free medium. Exp. Parasitol., 58: 72-80.

9. De Martini, G. J. W., Orrego, L. A., De Rissio, A. M., Alvarez, M., and Mujica, L. P., 1980. Cultivo de Trypanosoma cruzi en un medio monofasico. Su aplication en cultivos en gran escala en processos de fermentacion. Medicina (Buenos Aires), 40: 109-114.

10. Berens, R. L., Brun, R., and Krassner, S. M., 1976. A simple monophasic medium for axenic culture of hemoflagellates. J. Parasitol., 62: 360365.

11. Laemmli, U. K., 1970. Cleavage of structural proteins during the assembly of the head of bacteriophage T4. Nature, 227: 680-685.

12. Hendricks, L. D., Wood, D. E., and Hajduk, $M$ E., 1978. Haemoflagellates commercially available liquid media for rapid cultivation. Parasitology, 76: 309-316.

13. Berens, R. L., and Marr, J. J., 1978. An easily prepared defined medium for cultivation of Leishmania donovani promastigotes. J. Parasitol., 64: 160. 